\title{
Hydrochemical Characteristics and Ion Sources of River in the upstream of the Shiyang River, China
}

\author{
Zhiyuan Zhang ${ }^{1}$, Wenxiong $\mathrm{Jia}^{1}$, Guofeng Zhu ${ }^{1}$, Yang $\mathrm{Shi}^{1}$, Hui Xiong ${ }^{1}$, Le Yang ${ }^{1}$, Fuhua \\ Zhang $^{1}$, and Miaomiao Zhang ${ }^{1}$ \\ ${ }^{1}$ Northwest Normal University
}

October 28, 2020

\begin{abstract}
As the largest tributary of the Shiyang River, with the average annual inflow of total runoff accounting for $23 \%$, the Xiying River has representative of mountain runoff of inland rivers in the Northwest of China. Using samples collected in the Xiying River basin from September 2016 to October 2017, the water chemical composition and ion source characteristics of river was studied. The results show that the river is weakly alkaline, the average values of $\mathrm{pH}$ is 8.01 and the TDS is $179.29 \mathrm{mg} \cdot \mathrm{L}-1$. With the elevation decreasing along the river, the values of TDS of main stream tend to increase firstly and then decrease, but those of TDS of each tributary decrease, and latter is lower than the former. Affected significantly by the flow, the lowest value of ion concentration in river occurs in summer, and the highest value of it occurs in autumn and winter. The hydrochemical type of river is CaMg-HCO3. In the river, the order of cation mass concentration is $\mathrm{NH} 4+$
\end{abstract}

\section{Hosted file}

Article1027.pdf available at https://authorea.com/users/370757/articles/489322-hydrochemicalcharacteristics-and-ion-sources-of-river-in-the-upstream-of-the-shiyang-river-china

\section{Hosted file}

Figure and Table.pdf available at https://authorea.com/users/370757/articles/489322hydrochemical-characteristics-and-ion-sources-of-river-in-the-upstream-of-the-shiyangriver-china

\section{Hosted file}

Figure1-11.rar available at https://authorea.com/users/370757/articles/489322-hydrochemicalcharacteristics-and-ion-sources-of-river-in-the-upstream-of-the-shiyang-river-china 